The Canadian Journal of Higher Education, Vol. XXIII-1, 1993

La revue canadienne d'enseignement supérieur, Vol. XXIII-1, 1993

\title{
Academic Faculty Wives and Systemic Discrimination -Antinepotism and "Inbreeding"
}

\section{ANNE INNIS DAGG*}

\section{Abstract}

In the past, the academic careers of women married to professors have often been disadvantaged by anti-nepotism rules in universities and by informal department policies against hiring one's own Ph.D. graduates. To determine if these two systemic forms of discrimination, which especially affect faculty wives, are still operating, a study was made at a large university, the University of Waterloo. UW calendars show that some departments have hired academic spouses and many have hired their own Ph.D.s; however, a survey of UW professors indicates that a sizable number are against hiring spouses in a department and against a department hiring its own Ph.D.s. There is still cause for concern, therefore, if a university wants to hire the best candidate for a position and she happens to be a faculty wife.

\section{Résumé}

Dans le passé, l'accès des épouses de professeurs à des carrières académiques a souvent été limité par les règles en vigueur dans les universités visant à éliminer le népotisme dans les procédures d'engagement, et par les politiques départementales ne permettant pas l'accès des diplômés des programmes aux postes des mêmes départements. Une étude effectuée à l'Université de Waterloo a tenté d'établir si ces deux formes de discrimination systématique, qui affectent

* University of Waterloo. I would like to thank the many people who gave me information for this study. I am especially grateful to Ken Westhues and John Vardon who commented on earlier drafts of this paper, and to Jean Spowart who typed it. 
particulièrement les conjointes des professeurs, étaient toujours opérantes. Les annuaires de l'Université montrent que quelques départements ont passé outre à ces règles et ont engagé des épouses de professeurs ou des diplômés. Une enquête auprès du corps professoral de l'institution démontre, cependant, qu'une proportion importante des professeurs désapprouve ces initiatives. Il y a donc lieu de s'inquiéter si la meilleure candidate pour un poste n'est autre que l'épouse d'un professeur à la même institution.

In the early 1970s, under pressure from the women's movement, many North American universities carried out statistical analyses of their teaching staff and found that the proportion of women as full-time teachers was far lower than the proportion not only of female undergraduate students, but also of women with several degrees qualified to teach (Robinson, 1973; Hitchman, 1974). Expressing dismay at this finding, these universities announced plans to hire more women, either informally or formally, through affirmative action schemes. Despite their efforts, universities in the United States (Aisenberg \& Harrington, 1988) and Canada (Dagg \& Thompson, 1988) continue to have far fewer women than men teachers.

Academic faculty wives represent one group of potential female teachers who have been given little attention in previous research. These women have an ambivalent status. Until recently, most North American universities refused to hire them as teachers under anti-nepotism regulations (Bernard, 1964, pp. 102-5; Martin, 1975). Yet Myrna Weissman and her colleagues (1973), who carried out a survey of the employment and educational status of faculty wives at Yale University, found that a substantial number of them were "highly educated, academically inclined, career-minded women" who could find only low-status jobs or no paid work at all (p. 194). Indeed, faculty wives have included some of the world's most famous scientists, among them Nobel laureates Marie Curie, Gerty Cori, Dorothy Crowfoot Hodgkin, Maria Goeppert Mayer, and Rosalyn Yalow.

Two systemic university procedures, usually unofficial but nevertheless powerful, work against the hiring of academic faculty wives as opposed to women in general. One of these is opposition to nepotism in the hiring of wives of men currently employed in a university department; the other is opposition to the hiring of a university's own Ph.D.s. A wife often earns a Ph.D. from the local university where she is then unable to become a professor because of this opposition. Unlike many other women, she may not be free because of her marriage to seek a position at a university outside her locale, a dilemma which makes her career vulnerable to the local university's policies. 
These two areas are of concern because professors' wives are far more likely than other women to have academic interests, as noted for Yale (Weissman et al., 1973). Women graduate students are especially likely to meet and marry fellow graduate students or professors in their discipline. In one survey, 61 per cent of women doctorates in physical sciences and 45 per cent in biological sciences were married to men in the same or very closely related fields (Astin, 1969 , p. 29). At Berkeley, two-thirds of wives affected by the anti-nepotism regulation (96 per cent where the wife had a $\mathrm{Ph}$.D.) were in the same field as their husband (Sigworth, 1974, p. 118). In physics today, nearly half of women physicists are married to other physicists (Committee on the Status of Women in Physics of the American Physical Society, 1991). In the 1970s, 200 couples held joint membership in the American Psychological Association; nearly 20 per cent of the women felt they were exploited by universities and colleges which, because the women could not easily find other academic jobs, offered them less money than men would have received and non-regular appointments (Heckman, Bryson, \& Bryson, 1977). In departments where married couples are welcomed, such as the Psychology Department at the University of Waterloo, "of the seven full or part-time tenured women in the department..., five of them have husbands who also have faculty appointments" (Bowers, 1990, p. 2).

This paper considers the issues of university anti-nepotism and of department "inbreeding," first in North America generally and then at one large Ontario university, the University of Waterloo (UW). The UW data, consisting of statistics gathered from university calendars and of answers to questionnaires circulated to all university faculty, suggest that these two systemic areas of discrimination continue to work against a sizable group of academic women.

\section{A. Anti-Nepotism}

Nepotism was not uncommon in early American universities, where daughters, sisters and nieces of professors and other university men were often allowed to teach if they had the qualifications (Clifford, 1989, pp. 20-22). This situation was especially true at provincial, newly-established institutions where it was sometimes difficult to find faculty.

More recently, institutions have tended to favour policies of anti-nepotism, thus demonstrating that their faculty were hired and promoted on merit rather than as favourites of those in power. It was stated that nepotism might lead to the "appointment of the unfit, jealousy among colleagues, creation of a voting bloc, unearned advancement" (Dolan \& Davis, 1960, p. 295). A study by the American Association of University Women showed that in 1960, 52 per cent of a sample of colleges and universities in United States open to women had 
some regulations or policies that interfered with the employment of more than one member of a family on the faculty (Dolan \& Davis, 1960). At this time, a large survey of women with Ph.D.s found that about one-third of the women with husbands employed at academic institutions claimed they were adversely affected by anti-nepotism regulations (Simon, Clark, \& Tifft, 1966, p. 346). Ten years later, a study of American land-grant universities showed that 74 percent of them had some written policy pertaining to restricted employment of more than one family member (Martin, 1975, pp. 37-38). Some policies were so extreme that, if two people with tenure married, one had to relinquish that tenure (Dolan \& Davis, 1960, p. 294). Because such rules were almost always invoked against wives rather than husbands, they effectively discriminated against competent women. A study of Modern Language. Departments showed that universities with no anti-nepotism regulations had more women professors at every rank than universities with such regulations (Morlock, 1973, p. 265).

Anti-nepotism rules could undermine excellence in other ways, too. The above-cited study noted that experienced and established men sometimes left a university with stringent anti-nepotism rules because their highly-qualified wives could not be employed there. Other qualified men doubtless refused to accept work at universities where their wives were denied job opportunities.

The arbitrary exclusion of wives, the shortage of qualified teachers during the 1960s, and the increased pressure from feminists to hire more women teachers, has meant that universities have largely dropped anti-nepotism rules because they are in direct contradiction to affirmative action measures. Indeed, the references listed in CD-ROM Sociofile (from 1974 to April 1990) reveal no listings during that time for "nepotism and universities" or for "nepotism and education;" however, unwritten anti-nepotism practices have been so widespread in the past (Morlock, 1973 in Gappa \& Uehling, 1979, p. 51) that it is difficult to believe they have now disappeared entirely.

Unlike the United States, Canada has never had the hundreds of small, scattered private colleges and universities that hired many women faculty because they could not afford to hire men (Clifford, 1989, p. 5). In fact, Canadian universities have tended to hire few women. At Queen's University, for example, there were only eight women on faculty in 1950 ( $6 \%$ of the total), and in 1960 ten women (4.8\%) (Gibson, 1983, p. 344). At the University of British Columbia, founded in 1908, only one woman was hired before 1920 (Stewart, 1990, p. 84b). In University College at the University of Toronto, the first woman to hold a tenure-stream appointment in English was not hired until 1965. Other Toronto units which openly refused to hire women were the 
zoology department (to the 1930s) and Victoria College (to the 1940s) (Ford, 1985, pp. 59-60). The antipathy of some men to women professors is reflected in the disparaging remarks of one sociology professor, C.W. Hart, about "women and children" who had been hired to teach during and after the war (letter to H. A. Innis, Apr. 6, 1948). Women hired at Canadian universities were usually unmarried - for example, at McGill University and the University of Toronto (Gillett, 1981; Ford, 1985); however, when women professors were married, they were often married to other professors - for example, Professors Mossie May Kirkwood, Dorothea Walters, and Norma Ford Walker at the University of Toronto.

Anti-nepotism regulations involving the few married women were considered during the Great Depression of the 1930s. At that time, "the policy of McGill principal Sir Arthur Currie was not to employ husbands and wives," because of the widespread lack of jobs (Hoecker-Drysdale, 1990, p. 157). At the University of Toronto, there was talk of having academic faculty wives resign to save money (Ford, 1985, pp. 58-59). It is not known how widely anti-nepotism regulations have been applied since that time, but they may have partly accounted for the decline in the proportion of women faculty members in the 1950s (Vickers \& Adam, 1977, p. 114). Beginning in the 1960s, many academic couples have been hired at Canadian universities, although as recently as 1977, the Canadian Psychology Association encouraged the abolition of anti-nepotism rules (Report of the Task Force, 1977, p. 7). Earlier, in 1971, the Canadian Sociology and Anthropology Association (CSAA) told sociology departments in Canada to stop using marital status against women in hiring and tenure decisions $(1971$, p. 8); in 1973, the Canadian Association of University Teachers approved a policy to encourage universities not to discriminate against faculty wives, "although some administrations still try to do this in practice" (Blanchette \& Savage, 1991, p. 4). In 1972, a dean at the University of Waterloo told the author that he would never give a married woman tenure and he never did so during his terms in office.

\section{Status of Academic Faculty Wives at the University of Waterloo}

\section{a. Findings}

To determine the status of academic faculty wives connected with the University of Waterloo, a list was generated of all couples in two situations: where both members had taught there; and where one had taught there and the other at one of several nearby universities, either as regular faculty members or as yearly or sessional employees. The information was gathered from present 
and past university calendars listing teachers (but not usually sessionals); from discussions with people from departments across the campus; and from personal knowledge dating from the university's founding. Some sessional appointments not listed in calendars may have been missed.

i. During the past 30 years, 20 academic couples, each of whom had received (or were soon to receive) a Ph.D. from another university, moved to the UW area, where at least the husband would be employed. All of the women wanted jobs in academia and eventually obtained university jobs of some sort; but only five were hired for regular full-time positions in the same year as their husbands. Three of these were in the same department. The women were given either the same rank as their husbands or a lower one.

Seven of these women eventually acquired permanent full-time regular appointments at UW, although initially hired sometimes years later than their husbands, and usually at a lower rank and/or in part-time work. These realities set back their careers, sometimes slightly and often drastically. For example, two women were given tenure 18 and 20 years after first being hired part-time by the university.

Three have been unable to find full-time regular faculty positions but have worked or still work in academia in low status, usually part-time, jobs as researchers or lecturers. Four were not hired by their husbands' university but obtained full-time faculty positions at other universities at the same time or (in one case) years later.

ii. Thirty other academic couples both have Ph.D.s although they did not arrive together with them at the university; some married after one had a job at UW, and some wives earned their doctorates while married to UW professors. All the men either had or still have full-time faculty positions. Fourteen women who acquired their Ph.D.s from other universities or from UW ( 9 women) have regular faculty appointments. Five have been unable to find full-time regular faculty appointments but instead have worked at short-term or part-time positions with low status as researchers, advisors, or lecturers. One member each of twelve couples has a teaching position at another university.

iii. There were 28 academic couples of which only one member had a Ph.D. Only two had the men without Ph.D.s; both men taught in a program whose students hired them. Of the 26 couples in which the men but not the women had Ph.D.s, almost all of the women had two university degrees. Five of these women had regular full-time faculty positions (three in artistic, nontraditional disciplines), while 22 had low-status and/or part-time positions, two 
at a nearby university. Of these 22 women, nine taught only for a short period either because the university no longer wanted them, or because they went on to other work.

\section{b. Discussion}

At least 76 wives with and without Ph.D.s have been hired to teach at UW throughout the past 30 years, but many academic wives have been unable to establish a real career. At this university, 32 couples have (or had) regular faculty positions. Unlike husbands, most wives were hired on tenure stream once the university could evaluate them or their work in such jobs as part-time teaching, research, and definite-term appointments. Several women have proven so competent that they now outrank their husbands. The proportion of wives who are full professors is similar to that of women who are full professors $(6 \%-\mathrm{UW}$ statistics). In a few cases, wives were apparently hired because of pressure from their husbands, who had, or were promised, regular faculty positions.

A further 31 academic wives are (or were) employed at low-status, often part-time jobs, even though ten of these women have Ph.D.s. Universities benefit from having such an expendable labour force, one which not only receives low pay and few benefits, but also can be hired or fired at short notice in response to student enrollment (Dagg \& Thompson, 1988, pp. 74-75). Some of these women are content with their jobs if they are long-term; but others, especially those with Ph.D.s, feel exploited by the university, which currently admits it wants to hire more women because it has so few, but often passes over these part-time women no matter what their credentials might be. One woman found it hard to accept that she had put herself out to teach when her children were young, yet when they were older and she had more time, the university no longer wanted her. Only two men in this population, both without Ph.D.s, held low-status jobs compared to their wives. There is also a pool of unknown size of academic faculty wives with Ph.D.s who have been unable to obtain teaching jobs at any university. Thus there exists a sizable number of highly qualified faculty wives whose career potential is being wasted.

As an example of nepotism in the past, one modern language department at this university apparently decided not to allow faculty wives who were native-speakers of the language to instruct in that language, thereby denying work to several women eminently suitable for such jobs. Currently at this university, there is no policy of anti-nepotism in hiring within some departments, since a number of couples have regular appointments there. In at least one department, however, the chair stated that he would be loathe to hire a couple in his discipline and five years ago would have refused absolutely to do so. In 
cases where husbands and wives work in the same research areas, a circumstance not uncommon if they married as graduate students, at least two wives have been denied a real job; they note that when husbands and wives publish research together, the wife's contribution can easily be downgraded, thus undermining her career potential. They note also that, when the university can exploit their research and teaching through part-time or short-term appointments, it has little incentive to pay them far more as regular faculty appointees.

\section{Questionnaire on Hiring of Spouses}

Recent feeling toward hiring faculty spouses at UW has been ambiguous. Some departments have hired spouses, but some professors have strongly disapproved. One chair is definitely against such hirings, while others are uncertain. Since hiring decisions are usually made by hiring committees, comprising a number of professors, it was decided to survey the opinion of all UW professors by using a Faculty Association-sponsored questionnaire on this matter. It was circulated in February 1991.

The one-page questionnaire was completed by 304 faculty members for a return rate of $34 \%$; the respondents were $16 \%$ female, although only $12 \%$ of the UW faculty are women. It asked: "Do you think your department should hire as a faculty member the spouse of a faculty member who is a member of your department?" The respondent could answer "Yes/No/Uncertain" and add a comment if he or she so wished (Appendix A). Respondents were also asked to indicate their faculty, their department, their age range and their sex.

Most respondents $(73 \%)$ wrote short or up to page-long comments to accompany their "Yes/No/Uncertain" check-mark; these often indicated a degree of ambivalence, as well as a willingness to give the matter some thought. The responses indicated that $53 \%$ in all believed that excellence should be the only criterion in hiring professors, so that spouses should certainly be hired if they were the best person for the job (Table 1). A total of $30 \%$ believed that spouses should not be hired into the same department, indicating that preventing nepotism was of primary importance. Eighteen per cent were "uncertain." The responses varied by faculty, with Engineering (63\% Yes, 19\% No) most willing to put excellence above all else, and Science (43\% Yes, 37\% No) least willing to do so. The respondents most adamant against hiring spouses refused to name their faculty on the questionnaire.

Responses also differed by sex and by age (Table 2). Women were more likely than men to be agreeable to hiring spouses-indeed some mentioned being hired because this practice was allowed. Younger faculty members were 
Table 1

Responses to Question re: a UW Department Hiring Spouses as Faculty Members

\begin{tabular}{lcccc}
\hline Faculties & $\begin{array}{c}\text { Number of } \\
\text { Responses }\end{array}$ & Yes & No & Uncertain \\
\cline { 1 - 5 } Applied Health Sciences & 17 & $53 \%$ & $18 \%$ & $29 \%$ \\
Arts & 71 & $59 \%$ & $27 \%$ & $14 \%$ \\
Engineering & 59 & $63 \%$ & $19 \%$ & $19 \%$ \\
Environmental Studies & 20 & $55 \%$ & $35 \%$ & $10 \%$ \\
Mathematics & 46 & $46 \%$ & $30 \%$ & $24 \%$ \\
Science & 70 & $43 \%$ & $37 \%$ & $20 \%$ \\
Unstated & 21 & $48 \%$ & $48 \%$ & $5 \%$ \\
\hline Totals & 304 & $53 \%$ & $30 \%$ & $18 \%$ \\
\hline
\end{tabular}

more amenable to allowing spouses to be hired. Among the over-55s, a majority of those with firm opinions would have refused to hire spouses.

Those who answered "Yes" to the question were often adamant: "To deny a person a position merely on the grounds that they happen (at a point in time) to be married to someone strikes me as ludicrous."

There were several reasons given for hiring spouses:

- "I think that a couple often contribute more than two individuals."

- "I think that both spouses can be a positive strategy as we attempt to hire more women and to make Waterloo a university at which women can remain and at which their careers can develop alongside family life."

- "It seems like an ideal form of job sharing."

- "One way to attract underrepresented sexes is to hire a couple."

The professors who were negative to the proposition were often equally adamant in their position, again citing several reasons:

- "This has the disadvantage that other faculty see them as a team. It also has a disadvantage to the husband/wife. If either of them is denied tenure or promotion (etc.) it sours both of them on the department." 
Table 2

Responses by Sex and Age to Question re: Hiring Spouses as Faculty Members

\begin{tabular}{lrrrr}
\hline Sex & $\begin{array}{c}\text { Number of } \\
\text { Responses }\end{array}$ & Yes & No & Uncertain \\
$\quad$ Male & 236 & $51 \%$ & $30 \%$ & $19 \%$ \\
$\quad$ Female & 45 & $60 \%$ & $22 \%$ & $18 \%$ \\
& 281 & & & \\
Age & & & & \\
$\quad$ Under 41 & 78 & $56 \%$ & $21 \%$ & $23 \%$ \\
$\quad 41-55$ & 154 & $55 \%$ & $28 \%$ & $18 \%$ \\
$\quad$ Over 55 & 64 & $43 \%$ & $44 \%$ & $13 \%$ \\
& 296 & & & \\
\hline
\end{tabular}

- "Emphatically no! Nepotism presents very serious problems. Although this concept is supposed to help women, I think it simply keeps women academics in a secondary role. The man is hired and then insists we hire his wife. The wife is hired, and thus another woman (who doesn't have a husband to help her get hired) is given no chance for the job. "Open" competitions in such circumstances are farces. The husband and his friends in the department (or the wife and her friends) all vote to hire the dept. member's spouse."

- "I feel very strongly about this because I have seen what can be construed as favouritism in decisions during periods of financial crunch. Also, during periods of marital discord the tensions between the couple affect others with whom they work closely."

The comments of the respondents who marked "Uncertain," as well as some of those who marked "Yes" and "No," dwelt on the tension between the need to hire the strongest candidates and the dangers associated with nepotism. Many stipulated that spouses should be hired if they are the best qualified, but that care should be taken to prevent conflict of interest:

- "Faculty member should abstain from discussion of relative merits of candidate."

- "This can cause trouble, particularly if one of the pair gets an administrative position." 
- "If research interests overlap, then both they and the chair must take care that proper credit for research is allocated."

- "The job description could be intended to "fit" a spouse if he/she/it is acknowledged to be highly qualified. The description should never be adjusted just because someone is a spouse."

There were some disparate comments. A number mentioned problems of nepotism involving brother and father/son relationships. A few indicated the questionnaire was badly worded so that special attention should be given to comments; this was done. One man was annoyed because his wife had been shut out of staff jobs for which she was qualified.

\section{B. Department "Inbreeding"}

Also potentially harmful to faculty wives are policies or practices against "inbreeding." A faculty wife who wants to continue her education often earns a $\mathrm{Ph} . \mathrm{D}$. at the local university. If she decides to become a professor, she may find that the department has an informal rule against hiring its own doctoral students or for hiring them only after they have worked elsewhere for a few years. If she feels unable to leave the community because of her family, she may not be able to take full advantage of her higher education. Professorial sentiment against "inbreeding," then, is of particular importance to academic faculty wives.

The hiring of a university's own graduates many decades ago was often deemed beneficial. "Institutions have long recruited faculty disproportionately from among their alumni" (although alumni referred to those with bachelor's as well as higher degrees) (Clifford, 1989, p. 8). In many early American universities, such "inbreeding" fostered institutional loyalties, old-boys' networks, and a situation wherein appropriate religious responses were more important than external standards of scholarship. A president of Bucknell University hired over 80 per cent alumni, explaining that "the best men for us [are] our own men," since it took outsiders years to demonstrate appropriate institutional loyalty (Leslie in Clifford, 1989, p. 8). This trend did not benefit women, however, who were viewed as "the ultimate outsiders" (Clifford, 1989, p. 8).

At the University of Waterloo, some departments have hired their own doctoral students to regular faculty positions, but others have unofficial rules against doing this. One department head stated that he had angry comments from his faculty when he hired a woman newly graduated with a $\mathrm{Ph} . \mathrm{D}$. from his department, even though the department badly needed female faculty members; another said he would prefer never to hire one of his department's own 
graduates, but might be persuaded to do so if the applicant had worked elsewhere for some years.

A count of regular faculty members who have Ph.D.s from UW (1991-92 UW Calendar: Table 3) indicates that such hirings are rare in some faculties (Arts and Science) and common in others: they make up about one-quarter of the faculty in Applied Health Sciences and Engineering (which strongly support hiring new UW Ph.D.s), and one-fifth of the faculty in Mathematics (which does not). (Such hirings vary with departments, however; at the University of Toronto, 42 per cent of teachers of English hired up to 1984 had earned their highest degree from that university (Harris, 1988, Appendix 1).)

Table 3

Responses to Question re: a UW Department Hiring its New UW Ph.D. Graduates

\begin{tabular}{|c|c|c|c|c|c|}
\hline \multirow[b]{2}{*}{ Faculties } & \multirow{2}{*}{$\begin{array}{l}\text { Number of } \\
\text { Responses }\end{array}$} & \multicolumn{3}{|c|}{ Percentages } & \multirow{2}{*}{$\begin{array}{c}\text { Professors } \\
\text { with Waterloo } \\
\text { Ph.D.s* }\end{array}$} \\
\hline & & Yes & No & Uncertain & \\
\hline \multicolumn{6}{|c|}{ Applied Health } \\
\hline Sciences & 17 & $71 \%$ & $6 \%$ & $24 \%$ & $24 \%$ \\
\hline Arts & 71 & $35 \%$ & $48 \%$ & $17 \%$ & $5 \%$ \\
\hline Engineering & 59 & $59 \%$ & $24 \%$ & $17 \%$ & $25 \%$ \\
\hline \multicolumn{6}{|c|}{ Environmental } \\
\hline Studies & 20 & $60 \%$ & $25 \%$ & $15 \%$ & $13 \%$ \\
\hline Mathematics & 46 & $26 \%$ & $59 \%$ & $15 \%$ & $20 \%$ \\
\hline Science & 70 & $26 \%$ & $60 \%$ & $14 \%$ & $7 \%$ \\
\hline Unstated & 21 & $33 \%$ & $43 \%$ & $24 \%$ & \\
\hline Totals & 304 & $40 \%$ & $43 \%$ & $17 \%$ & $14 \%$ \\
\hline
\end{tabular}




\section{Questionnaire on "Inbreeding"}

The other question on the questionnaire sent to UW faculty was: "Do you think your department should hire a candidate who has just obtained a UW doctorate from your department?" (Appendix A).

Many respondents were also ambivalent about this issue, and $75 \%$ wrote comments. In all, $40 \%$ felt that yes, the best must be hired, no matter what, so that it was appropriate to hire one's own doctorates (Table 3). Slightly more, $43 \%$, felt that no, such academics should not be hired; and $17 \%$ were uncertain about how they felt. Again, the responses varied markedly by faculty. The faculty in Applied Health Studies felt most strongly that a department should hire its own doctorates if these were the best qualified (71\% Yes and $6 \%$ No); Mathematics and Science professors were most opposed to this possibility (26\% Yes and 59\%/60\% No).

The responses varied by sex but not by age (Table 4). Men felt more strongly than women that a department should feel free to hire its own doctorates. There was no consensus about this issue on the basis of age.

The comments for this question ranged from very positive to very negative. Those who marked "Yes" believed that a UW Ph.D. will know how the university functions, just as the faculty will know his or her strengths and weaknesses. One wrote:

I find it inconceivable that we should attract superior graduate students and then disqualify them because they had studied at Waterloo. If this policy were to be adopted we should indicate to graduate students that by coming to Waterloo they would be

Table 4

Responses by Sex and Age to Question re: Hiring New UW Ph.D. Graduates

Sex

Number of

Responses Yes No Uncertain

Male

236

$42 \%$

$43 \%$

$15 \%$

Female

$29 \%$

$47 \%$

$24 \%$

281

Age

\begin{tabular}{lrlll} 
Under 41 & 78 & $41 \%$ & $46 \%$ & $13 \%$ \\
$41-55$ & 154 & $37 \%$ & $42 \%$ & $21 \%$ \\
Over 55 & 64 & $40 \%$ & $46 \%$ & $14 \%$ \\
& 296 & & & \\
\hline
\end{tabular}


ineligible for employment at $\mathrm{U}$ of $\mathrm{W}$ even though they may be the best candidate.

The professors who answered "No" to the question often had comments such as the following:

- "Unless it is of exceptional qualifications and the candidate's Ph.D. supervisor has left the department."

- "Too much struggle to gain independence and be seen as someone to be taken seriously as a colleague. I've seen it cause outrageous behaviour on the new faculty member and insufferable condescension by older members."

- "I know of some departments in Canada who hire their own students and the long term effect is very deleterious for them."

- "I feel we should be doing more to encourage dispersion of our talent and hiring from outside. Otherwise we run the real risk of turning into academic hillbillies (in a gene pool sense)."

The professors who answered the question with "Uncertain", and some also who answered "Yes" or "No", were torn in their comments between wanting to hire the best possible candidate, whether a graduate of UW or elsewhere, and wanting to do what was best for the department and the UW candidate. Thirty-six indicated they would be willing to hire a Waterloo doctorate if he or she had spent time (six months, to two or three years, or up to seven years) away from Waterloo working as a post-doctoral fellow or in industry. Other professors were ambivalent, as noted here:

- "If a "star professor" leaves our university, then a bright (very) student of the star professor would be an appropriate candidate for consideration."

- "In general, I am dead against "excessive" in-breeding" -defined as more than about $30 \%$ of faculty.

\section{Discussion and Conclusion}

Two systemic forms of discrimination in universities may act against academic faculty wives: an unwillingness to hire spouses in the same department, and a reluctance to hire the insitution's own Ph.D.s. In the University of Waterloo, a number of academic wives have sooner or later been hired to regular faculty positions; but many have been able to find only short-term or part-time jobs, or no jobs at all, despite being highly qualified. It is impossible to know how many 
academic faculty wives have been denied careers at UW because of their marital status; but it is clear that a sizable minority of professors believe they should not be hired in the same department as their husbands and that they should not be hired in a department from which they earned their Ph.D.

Academic faculty wives are also ambivalent about their university jobs. Many feel great tension between creating a good marriage and having a top career (Aisenberg \& Harrington, p. 7, Chap. 5). Some, especially those without a Ph.D., are happy to have university jobs, while others feel exploited because their jobs have no future; no matter how well they teach or how much research they do, many women with doctorates have no real university career. These women are at a disadvantage in the academic job market because of their lack of mobility. Typically, they have settled with their husbands at universities where a qualified person of their area of expertise is not wanted. If they wish to remain in academia, they may have to accept low-status jobs at their husbands' university or commute to other universities. Such commuting is especially difficult if the couple has children and if long distances are involved, although it has become increasingly common as more women earn Ph.D.s.

The issue of academic faculty wives is filled with perplexing dichotomies. Society as well as universities see women as secondary to men, and wives as secondary to husbands; yet sexual discrimination is also perceived as a bad thing. Universities are willing to hire academic wives for low status, low-paying jobs for which they are overqualified, but are unwilling to promote them to top ranks. Universities complain about a lack of money, yet they pass over for jobs these qualified women to whom they could (but of course should not) pay less money than comparable men. Universities say they want (or have) the best faculty possible; yet they make little effort to hire a balance of women and men professors essential for good teaching, balanced research, and role modelling for students.

There is strong evidence of systemic bias against academic faculty wives in the university studied here; and undoubtedly systemic bias exists in other universities too. Universities should therefore review their formal and informal policies to detect possible systemic discrimination and then act to ensure that it does not disadvantage this group of academics. If a department is small, hiring and promotion committees should include representatives from cognate departments and the wider university, in order to ensure fairness. All such committees should include members of each sex. Universities could also in the future make better use of academic faculty wives if they were to decentralize their operations and set up or improve their distance education opportunities. 
Couples employed full-time at a university provide it with stability and loyalty, since it is unlikely they would both be hired in comparable jobs elsewhere. Academic wives help make a university a place "at which women can remain and at which their careers can develop alongside family life," to quote one questionnaire respondent. These aspects of role modelling are important for both men and women students and for the university community as a whole. A university cannot attain excellence if it has practices that prevent excellent candidates from being hired.

\section{References}

Aisenberg, N., \& Harrington, M. (1988). Women of academe: Outsiders in the sacred grove. Amherst, MA: University of Massachusetts Press.

Astin, H.S. (1969). The woman doctorate in America. New York: Russell Sage Foundation.

Bernard, J. (1964). Academic women. University Park: Pennsylvania State University Press.

Blanchette, M., \& Savage, D. (1991). Employment equity at CAUT: a historical perspective. Canadian Association of University Teachers Status of Women Supplement, April.

Bowers, K.S. (1990, Nov. 7). Letter to the Editor. University of Waterloo Gazette.

Canadian Sociology and Anthropology Association. (1971, April). Bulletin.

Clifford, G.J. (1989). Lone voyagers: Academic women in coeducational universities, 1870-1937. New York: Feminist Press.

Committee on the Status of Women in Physics of the American Physical Society. (1991, February). APS membership survey reveals characteristics of women members. Gazette 11(1), 6-7.

Dagg, A.I., \& Thompson, P.J. (1988). MisEducation: Women and Canadian universities. Toronto: OISE Press.

Dolan, E.F., \& Davis, M P. (1960). Antinepotism rules in Amcrican colleges and universities. Educational Record, 285-95.

Ford, A.R. (1985). A path not strewn with roses. One hundred years of women at the University of Toronto 1884-1984. Toronto: University of Toronto Press.

Gappa, J.M., \& Uehling, B. S. (1979). Women in academe. Washington, DC: American Association for Higher Education, pp. 49-52.

Gibson, F.W. (1983). Queen's University Vol. II 1917-1961. To serve and yet be free. Kingston: McGill-Queen's University Press.

Gillett, M. (1981). We walked very warily. A history of women at McGill. Montreal: Eden Press.

Harris, R. (1988). English studies at Toronto: A history. Toronto: University of Toronto Press.

Hart, C.W. (1948). Letter to Harold A. Innis, Apr. 6, 1948. In University of Toronto Archives.

Heckman, M.A., Bryson, R., \& Bryson, J. (1977). Problems of professional couples: a content analysis. Journal of Marriage and Family, 39, 323-30. 
Hitchman, G.S. (1974, October). A report on the reports: The status of women in Canadian sociology. Canadian Sociology and Anthropology Association Bulletin, 35, 11-13.

Hoecker-Drysdale, S. (1990). Women sociologists in Canada: The careers of Helen MacGill Hughes, Aileen Dansken Ross, and Jean Robertson Burnet. In M. G. Ainley (Ed.), Despite the odds (pp. 152-176). Montreal: Véhicule Press.

Martin, D. (1975). The wives of academe. In Change, Women on campus (pp. 35-43). New York: New Rochelle.

Morlock, L. (1973). Discipline variation in the status of academic women. In A. S. Rossi and A. Calderwood (Eds.), Academic women on the move, (pp. 255-312), New York: Russell Sage Foundation.

Report of the task force on the status of women in Canadian psychology, Mar. 1976. (1977). Canadian Psychological Review 18, (1), 3-18.

Robinson, L.H. (1973). Institutional variation in the status of academic women. In A. S. Rossi and A. Calderwood (Eds.) Academic women on the move (pp. 199-238), New York: Russell Sage Foundation.

Sigworth, H. (1974). Issues in nepotism rules. In W. T. Furniss \& P. A. Graham (Eds.) Women in higher education, (pp. 110-120). Washington, DC: American Council on Education.

Simon, R.J., Clark, S.M. \& Tifft, L L. (1966). Of nepotism, marriage, and the pursuit of an academic career. Sociology of Education, 39, 344-58.

Stewart, L. (1990). "It's up to you": Women at UBC in the early years. Vancouver: University of British Columbia Press.

Vickers, J. M. \& Adam, J. (1977). But can you type? Canadian universities and the status of women. Toronto: Clarke, Irwin.

Weissman, M.M., Nelson, K., Hackman, J., Pincus, C., \& Prusoff, B. (1973). The faculty wife: Her academic interests and qualifications. In A. S. Rossi \& A. Calderwood (Eds.) Academic women on the move, (pp. 187-195). New York: Russell Sage Foundation.

\section{APPENDIX A}

\section{FAUW Questionnaire}

Some candidates who apply for positions at the University of Waterloo:

(i) are married to another professor in the same department, andlor

(ii) have just received their Ph.D. from UW.

These hiring areas are sensitive, and we would like to see these candidates considered fairly, objectively and in the best interests of UW scholarship. Because the Faculty Association participates in the development of UW policies and procedures, the Association would like to ascertain how professors on our campus feel about these issues and concerns. Your opinion is valuable to the Faculty 


\section{Anne Innis Dagg}

Association, and we would ask you to take a few moments to respond to this questionnaire.

1. Do you think your department should hire a candidate who has just obtained a UW doctorate from your department?

[ ] Yes

[ ] No

[ ] Uncertain

Comment:

2. Do you think your department should hire as a faculty member the spouse of a faculty member who is a member of your department?
[] Yes
[ ] No
[ ] Uncertain

Comment:

Department ?

Faculty?

Male?

Female?
Age [ ] Under 41

[ ] $41-55$

[ ] Over 55 